\title{
The Bacterial Quality of Lake Waters at Yellowknife, Northwest Territories
}

\author{
J. B. BELL, J. F. J. ZAAL and J. M. VANDERPOST ${ }^{1}$
}

\begin{abstract}
A study was conducted to measure the degree of contamination of lake waters at Yellowknife produced by the disposal of domestic wastes, and to assess the suitability of these waters for domestic use. None of the samples analysed met Canadian standards for drinking water. Though the bacterial quality of the main body of water was found to be good, there was contamination at points of discharge of sewage and near storm drains, marsh muds and sediments. It is recommended that the City of Yellowknife seek an alternative site for sewage disposal and give adequate publicity to the dangers of using inadequately treated water.
\end{abstract}

\begin{abstract}
RÉSUMÉ. La qualité bactérienne des eaux lacustres d Yellowknife, Territoires du Nord-Ouest. Une étude a été menée afin de mesurer le degré de contamination des eaux lacustres de Yellowknife produite par l'écoulement des déchets domestiques et d'évaluer la salubrité de ces eaux destinées à l'usage domestique. Aucun des prélèvements analysés ne se conformait aux standards canadiens régissant l'eau potable. Bien que la qualité bactérienne de l'ensemble des eaux ait été bonne, on trouva de la contamination aux points de déversement des égouts dans les lacs, près des bouches d'égouts, dans la boue et sédiments marécageux. On a recommandé à la ville de Yellowknife de trouver un autre endroit pour le déchargement des égouts et de faire une publicité suffisante pour mettre le public en garde contre les dangers d'utiliser des eaux inadéquatement traitées.
\end{abstract}

\begin{abstract}
РЕЗЮМЕ. Содержание бактерий в озерной воде в районе ә. Йеллоунайфба, Северо-Западные территории. Изучалась степень загрязнения озерноң воды городскимн отходами в районе Йеллоунайфа, и проводилась оценка пригодности этой воды для бытового потребления. Ни одна из проанализированных проб не отвечала канадским стандартам для питьевон воды. Хотя содержание бактерий в основной массе воды было найдено удовлетворительным, значительный уровень загрязнения имел место в местах сброса сточных вод, вблизи ливневых колекторов, а также в болотной трязи и наносах. Была подана рекомендация, в которой предлагалось, чтобы администрация г. Йеллоунай рассмотрела новые места для сброса сточных вод, а также информировала население о вовможных последствиях испольвования недостаточно очищенног воды.
\end{abstract}

\section{INTRODUCTION}

Yellowknife is the largest city in the Northwest Territories of Canada. Its present population of 9,800 will, according to current predictions, increase to 16,300 by 1990 (Pick 1975). The disposal of its domestic waste has been achieved by lagooning in a small lake (Niven Lake) with subsequent discharge to Back Bay which forms an area of Yellowknife Bay on the northern shores of Great Slave Lake (approximately $114^{\circ} 25^{\prime} \mathrm{W}, 62^{\circ} 26^{\prime} \mathrm{N}$ ). Grainge (1971) suggested that Niven Lake was providing poor treatment and that an alternative means of sewage disposal should be sought. He noted in the same report that the effluent was not

\footnotetext{
${ }^{1}$ Environment Canada, Microbiology Laboratory, 5320 - 122 Street, Edmonton, Alberta, Canada.
} 
disinfected and that the receiving water was unsuitable for drinking.

Public health problems are not a novelty in the North although identification of waterborne routes of infection is often difficult. McCabe and Craun (1975) reported 112 cases of gastroenteritis among persons consuming water at a roadside restaurant on the Alaska Highway between Tok Junction and Whitehorse. Yamamoto (1975) has made reference to outbreaks of infectious hepatitis in the Canadian North, including a 1973 outbreak of 288 cases in the Baffin region (thirteen communities with a total population of 7,000, lying between Arctic Bay and Frobisher Bay). Yamamoto (1975) also demonstrated the presence of a large number of viruses (110 plaque-forming units per litre) in the sewage effluent from Niven Lake.

The dissemination of large numbers of bacteria, particularly bacterial pathogens, relating as it does to the associated problems of water supply and sewage disposal, is perhaps of more concern in the North than elsewhere, for these organisms survive longer at low temperatures. Salmonella, a bacterial pathogen, has been shown to survive at least seven days in the Tanana River (Van Donsel et al. 1974), and the organisms associated with the presence of bacterial pathogens, coliforms, faecal coliforms and faecal streptococci, have been shown to have similar survival rates in the same river (Gordon 1972.) The water temperature of the Tanana River was $0^{\circ} \mathrm{C}$ at the time of the two studies.

Many small settlements in the North do not have a central water supply or waste disposal system. Even in larger communities such as Yellowknife, only part of the town is on such a system. Heinke and Deans (1973) have shown that a great deal of the water of Frobisher Bay, N.W.T. $\left(64^{\circ} \mathrm{N}, 63^{\circ} 30^{\prime} \mathrm{W}\right)$ is supplied by truck, and its sewage disposal is accomplished by "honey bags" or by storage in a holding tank with subsequent trucking to a central location. This is analogous to the situation in "Old Town," a section of Yellowknife largely inhabited by native people, transients and squatters. While most of the inhabitants of "Old Town" are supplied with trucked or piped water during summer, there are a number of dwelling places along the shores of Back Bay and Yellowknife Bay and locations on nearby islands where the only fresh water comes from these bays, into which an unsterilized sewage effluent is directly discharged.

In the light of these facts, a study was undertaken by Environment Canada to assess the effects, and define the zone of influence, of the Niven Lake discharge; to assess the bacterial quality of those waters likely used as a domestic supply by local inhabitants; to define other point sources of bacterial pollution and, on the basis of the findings, to make recommendations to the water authorities of the City of Yellowknife and the North West Territories.

\section{METHOD OF STUDY}

Water samples were collected from a depth of one metre at each of the water quality monitor stations shown on Fig. 1 . The samples were taken eight times during the period 2 September to 7 October 1975. The sewage effuent zone was sampled three times under varying weather conditions, and the potable water stations were sampled once. The point-source stations (Fig. 2) were sampled once 


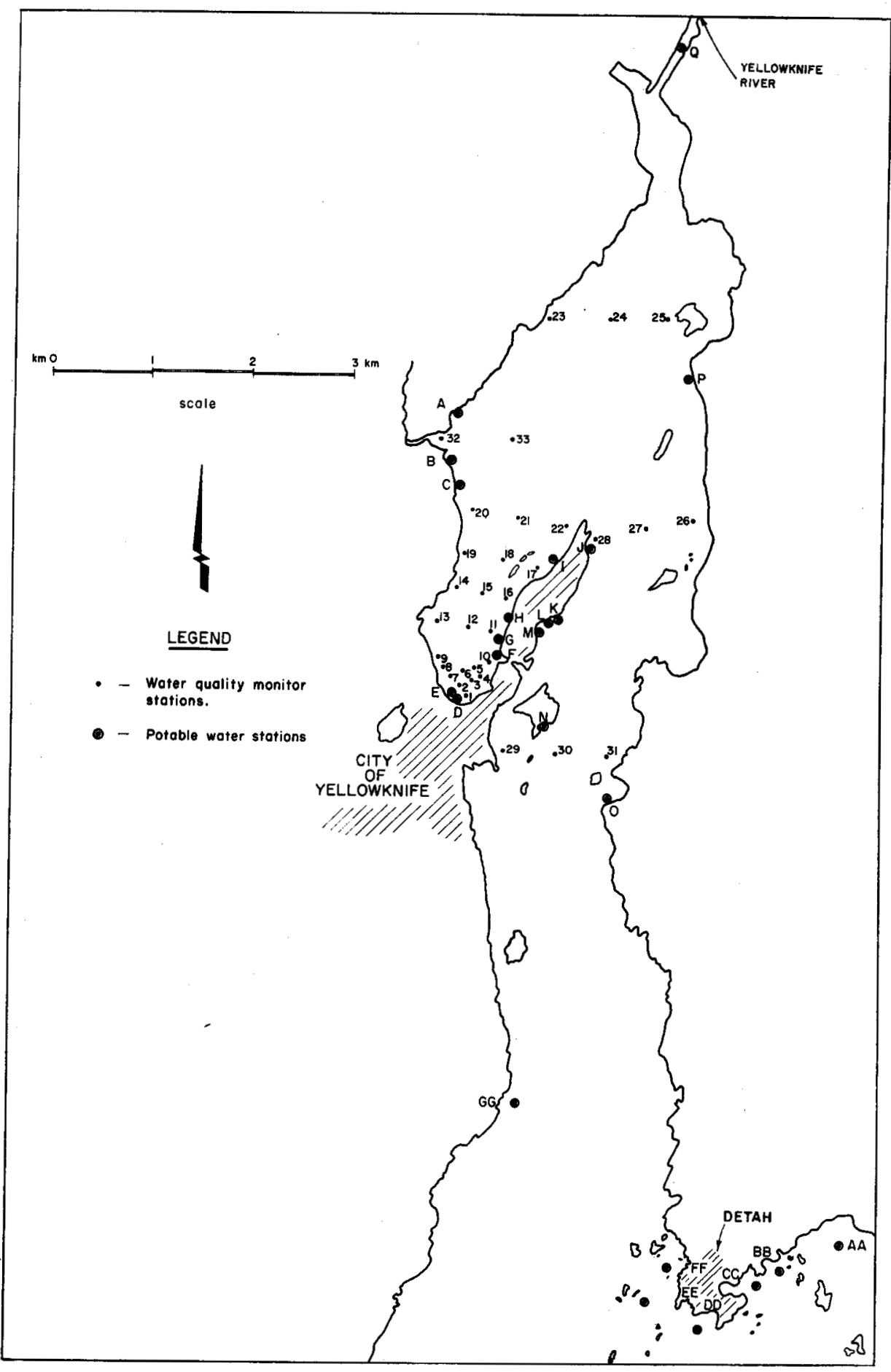

Fio. 1 Sampling locations, Back Bay and Yellowknife Bay. 


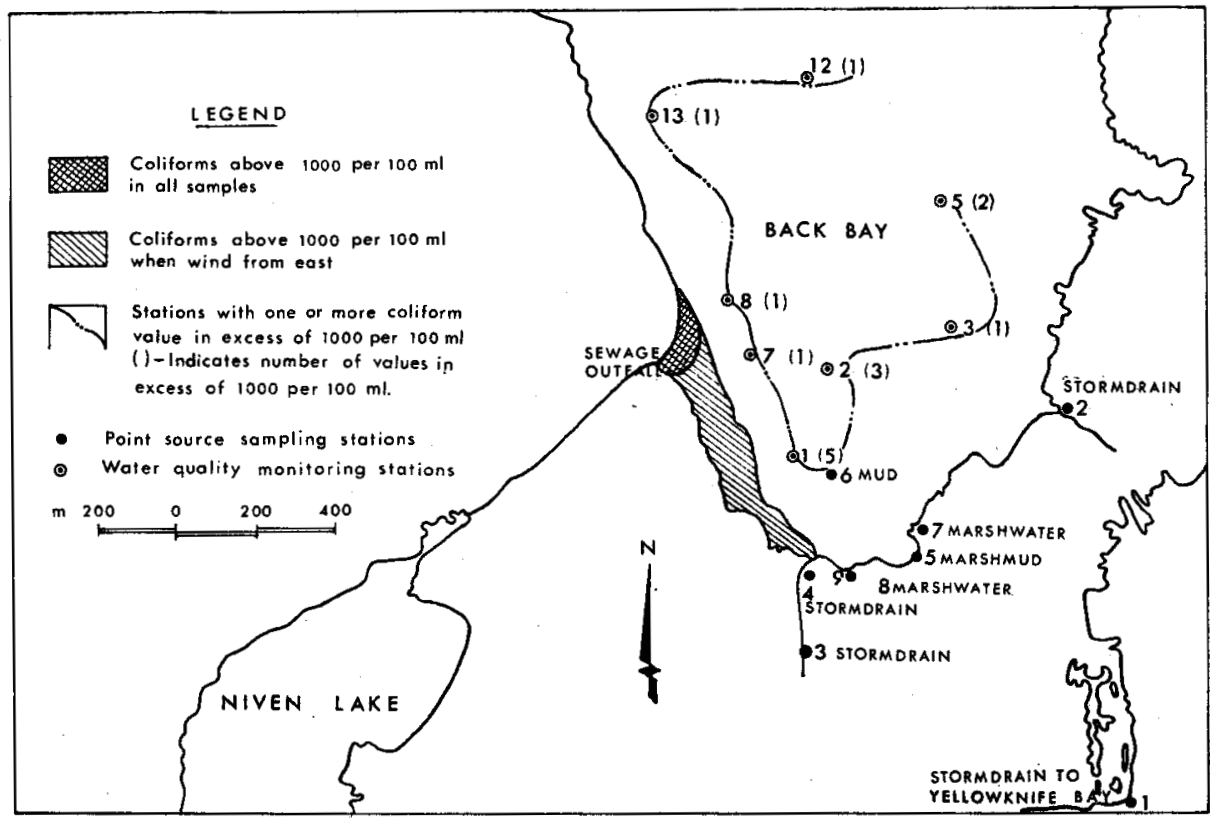

Fig. 2 Zone of influence of sewage outfall at Back Bay and of other point source sampling stations.

during a period of rainfall. Samples of sewage influent and effluent were collected eight times during the study period.

Bacterial analyses for total coliform, faecal coliform, faecal streptococci, standard plate counts (S.P.C.) at $20^{\circ} \mathrm{C}$ and $35^{\circ} \mathrm{C}$, and spread plate counts at $20^{\circ} \mathrm{C}$ were conducted in a field laboratory, usually within two to eight hours of the time the samples were collected. All samples were subjected to standard membrane filtration procedures (A.P.H.A. 1971) for total coliforms, faecal coliforms and faecal streptococci, the medium of choice being LES Endo Agar, M-FC Agar and M-Enterococcus Agar respectively. Standard plate counts were performed according to the pour-plate method (A.P.H.A. 1971) with incubation periods of $24 \pm 2$ hours and $48 \pm 2$ hours for the $35^{\circ} \mathrm{C}$ and $20^{\circ}$ counts respectively. Spread plate counts at $20^{\circ} \mathrm{C}$ were determined by the medium and method, as previously described by Bell and Jurkovic (1975) with an incubation period of 7 days. All methods have been described in detail by Bell (1975).

\section{RESULTS AND DISCUSSION}

In general, the bacterial quality of Back Bay and Yellowknife Bay can be considered good, although disinfection would be required before their water could be used for domestic consumption. The geometric mean coliform values for three sectors were respectively 360,130 and 30 per 100 millilitres (ml) (see Table 1). These values are comparable to those reported by Bell and Vanderpost (1973) for Lake Ontario in areas where Lake Ontario was considered unpolluted. Although the values are low for the indicator organisms, the presence of bacterial 
TABLE 1. Analysis of samples from water quality monitor stations

\begin{tabular}{|c|c|c|c|c|c|c|c|}
\hline \multirow[b]{2}{*}{ Station } & \multirow{2}{*}{$\begin{array}{c}\text { Total } \\
\text { coliform } \\
\text { per } 100 \mathrm{ml}\end{array}$} & \multirow{2}{*}{$\begin{array}{c}\text { Faecal } \\
\text { coliform } \\
\text { per } 100 \mathrm{ml}\end{array}$} & \multirow{2}{*}{$\begin{array}{c}\text { Faecal } \\
\text { streptococci } \\
\text { per } 100 \mathrm{ml}\end{array}$} & \multirow[b]{2}{*}{ F.C./F.S. } & \multicolumn{2}{|c|}{$\begin{array}{l}\text { Standard plate } \\
\text { counts per ml }\end{array}$} & \multirow{2}{*}{$\begin{array}{c}\begin{array}{c}\text { Spread plate } \\
\text { counts per ml }\end{array} \\
20^{\circ} \mathrm{C}\end{array}$} \\
\hline & & & & & $35^{\circ} \mathrm{C}$ & $20^{\circ} \mathrm{C}$ & \\
\hline \multicolumn{8}{|l|}{ Sector 1} \\
\hline $\begin{array}{r}1 \\
2 \\
3 \\
4 \\
5 \\
6 \\
7 \\
8 \\
9 \\
10\end{array}$ & $\begin{array}{l}780 \\
390 \\
260 \\
260 \\
330 \\
250 \\
390 \\
490 \\
500 \\
150\end{array}$ & $\begin{array}{r}16 \\
12 \\
12 \\
10 \\
10 \\
7 \\
15 \\
16 \\
23 \\
16\end{array}$ & $\begin{array}{l}3 \\
2 \\
2 \\
2 \\
4 \\
2 \\
2 \\
4 \\
3 \\
3\end{array}$ & $\begin{array}{l}4.00 \\
5.89 \\
6.47 \\
5.36 \\
3.85 \\
4.87 \\
7.00 \\
3.99 \\
9.10 \\
5.00\end{array}$ & $\begin{array}{l}48 \\
45 \\
69 \\
41 \\
41 \\
34 \\
67 \\
80 \\
90 \\
71\end{array}$ & $\begin{array}{r}190 \\
110 \\
170 \\
86 \\
120 \\
100 \\
120 \\
230 \\
240 \\
130\end{array}$ & $\begin{array}{l}5,300 \\
6,600 \\
4,300 \\
3,200 \\
5,500 \\
6,500 \\
7,200 \\
7,100 \\
8,300 \\
5,400\end{array}$ \\
\hline $\begin{array}{l}\text { Geom. } \\
\text { means }\end{array}$ & 360 & 13 & 3 & 5.61 & 59 & 140 & 5,900 \\
\hline \multicolumn{8}{|l|}{ Sector 2} \\
\hline $\begin{array}{c}11 \\
12 \\
13 \\
14 \\
15 \\
16 \\
17 \\
18 \\
19 \\
20 \\
21 \\
22 \\
\text { Geom. }\end{array}$ & $\begin{array}{r}220 \\
380 \\
470 \\
220 \\
230 \\
160 \\
70 \\
85 \\
95 \\
58 \\
53 \\
63\end{array}$ & $\begin{array}{r}12 \\
15 \\
32 \\
10 \\
7 \\
6 \\
2 \\
1 \\
4 \\
3 \\
2 \\
2\end{array}$ & $\begin{array}{l}2 \\
2 \\
3 \\
2 \\
2 \\
1 \\
1 \\
1 \\
1 \\
1 \\
1 \\
1\end{array}$ & $\begin{array}{r}5.33 \\
7.05 \\
9.04 \\
7.29 \\
4.94 \\
4.46 \\
1.14 \\
5.57 \\
3.93 \\
-\end{array}$ & $\begin{array}{r}68 \\
60 \\
140 \\
55 \\
67 \\
29 \\
28 \\
17 \\
33 \\
18 \\
17 \\
25\end{array}$ & $\begin{array}{r}140 \\
210 \\
410 \\
120 \\
150 \\
95 \\
68 \\
48 \\
67 \\
51 \\
52 \\
58\end{array}$ & $\begin{array}{r}3,900 \\
4,800 \\
9,400 \\
4,800 \\
3,200 \\
6,000 \\
1,400 \\
2,900 \\
1,500 \\
1,100 \\
1,400 \\
890\end{array}$ \\
\hline means & 130 & 6 & 1 & 5.17 & 37 & 97 & 2,700 \\
\hline \multicolumn{8}{|l|}{ Sector 3} \\
\hline $\begin{array}{l}23 \\
24 \\
25 \\
26 \\
27 \\
28 \\
29 \\
30 \\
31 \\
32 \\
33\end{array}$ & $\begin{array}{l}37 \\
34 \\
30 \\
29 \\
32 \\
32 \\
72 \\
32 \\
15 \\
36 \\
11\end{array}$ & $\begin{array}{l}1 \\
1 \\
2 \\
1 \\
2 \\
1 \\
7 \\
3 \\
2 \\
2 \\
1\end{array}$ & $\begin{array}{l}1 \\
1 \\
1 \\
1 \\
1 \\
1 \\
4 \\
1 \\
1 \\
1 \\
1\end{array}$ & $\begin{array}{r}= \\
= \\
\overline{-} \\
1 . \overline{85} \\
4.00 \\
1 . \overline{24} \\
-\end{array}$ & $\begin{array}{r}25 \\
14 \\
8 \\
22 \\
21 \\
20 \\
37 \\
24 \\
24 \\
20 \\
24\end{array}$ & $\begin{array}{l}69 \\
48 \\
35 \\
52 \\
50 \\
48 \\
82 \\
74 \\
68 \\
61 \\
50\end{array}$ & $\begin{array}{r}600 \\
1,100 \\
600 \\
770 \\
950 \\
1,200 \\
560 \\
540 \\
820 \\
1,800 \\
700\end{array}$ \\
\hline means & 30 & 2 & 1 & 1.51 & 20 & 56 & 810 \\
\hline
\end{tabular}

pathogens such as Salmonella is possible. Dutka and Bell (1973) demonstrated the presence of Salmonella in the Kingston to Brockville (seaway in mileage 185 to 136) section of the St. Lawrence River where the coliform values were less than 20 per $200 \mathrm{ml}$.

None of the water samples analysed met the Canadian standards (D.N.H.W. 1968) by coliform values, which varied from 6 per $100 \mathrm{ml}$ to 47,000 per $100 \mathrm{ml}$ in the Back Bay and Yellowknife Bay areas (Table 2). At Detah the values were lower, with the coliform values varying from 1 to 78 per $100 \mathrm{ml}$ (Table 3). Although the coliform values of the potable water supplies are generally low, 
TABLE 2. Analysis of possible potable water supply in the Back Bay and Yellowknife area

\begin{tabular}{|c|c|c|c|c|c|c|c|c|}
\hline \multirow[b]{2}{*}{ Date } & \multirow[b]{2}{*}{ Station } & \multirow{2}{*}{$\begin{array}{c}\text { Total } \\
\text { coliform } \\
\text { per } \\
100 \mathrm{ml}\end{array}$} & \multirow{2}{*}{$\begin{array}{c}\text { Faecal } \\
\text { coliform } \\
\text { per } \\
100 \mathrm{ml}\end{array}$} & \multirow{2}{*}{$\begin{array}{c}\text { Faecal } \\
\text { streptococci } \\
\text { per } \\
100 \mathrm{ml}\end{array}$} & \multirow{2}{*}{ F.C./F.S. } & \multicolumn{2}{|c|}{$\begin{array}{l}\text { Standard plate } \\
\text { counts per ml }\end{array}$} & \multirow{2}{*}{$\begin{array}{c}\begin{array}{c}\text { Spread } \\
\text { plate } \\
\text { counts } \\
\text { per ml }\end{array} \\
20^{\circ} \mathrm{C}\end{array}$} \\
\hline & & & & & & $35^{\circ} \mathrm{C}$ & $20^{\circ} \mathrm{C}$ & \\
\hline $\begin{array}{r}1 \text { Oct. } \\
29 \text { Sept. } \\
29 \text { Sept. } \\
30 \text { Sept. } \\
4 \text { Oct. } \\
1 \text { Oct. } \\
4 \text { Oct. } \\
4 \text { Oct. } \\
6 \text { Oct. } \\
29 \text { Sept. } \\
30 \text { Sept. } \\
30 \text { Sept. } \\
1 \text { Oct. } \\
1 \text { Oct. } \\
1 \text { Oct. } \\
1 \text { Oct. } \\
1 \text { Oct. } \\
6 \text { Oct. }\end{array}$ & $\begin{array}{l}\text { A } \\
\text { B } \\
C \\
D \\
\text { E } \\
\text { F } \\
\text { G } \\
\text { H } \\
\text { I } \\
J \\
K \\
\text { L } \\
\text { M } \\
\text { D } \\
\text { D } \\
\text { P } \\
Q \\
Q\end{array}$ & $\begin{array}{r}58 \\
46 \\
6 \\
500 \\
47,000 \\
60 \\
160 \\
120 \\
88 \\
70 \\
46 \\
28 \\
10 \\
16 \\
15 \\
37 \\
34 \\
28\end{array}$ & $\begin{array}{r}<2 \\
2 \\
1 \\
16 \\
910 \\
40 \\
42 \\
22 \\
<2 \\
<1 \\
2 \\
<1 \\
<2 \\
<2 \\
2 \\
<2 \\
<2 \\
<2\end{array}$ & $\begin{array}{r}<1 \\
<1 \\
<1 \\
2 \\
290 \\
<1 \\
8 \\
4 \\
<2 \\
<1 \\
<1 \\
<1 \\
<1 \\
\quad 13 \\
1 \\
4 \\
<1 \\
<2\end{array}$ & $\begin{array}{l}8.00 \\
3.14 \\
\\
5.25 \\
5.50\end{array}$ & $\begin{array}{r}14 \\
29 \\
22 \\
100 \\
1,600 \\
24 \\
50 \\
40 \\
8 \\
66 \\
21 \\
8 \\
7 \\
15 \\
8 \\
21 \\
8 \\
4\end{array}$ & $\begin{array}{r}83 \\
58 \\
38 \\
94 \\
\text { Lost } \\
280 \\
450 \\
1,600 \\
75 \\
65 \\
15 \\
7 \\
30 \\
41 \\
37 \\
50 \\
40 \\
87\end{array}$ & $\begin{array}{r}290 \\
990 \\
810 \\
6,000 \\
250,000 \\
6,100 \\
11,000 \\
15,000 \\
\text { No Data } \\
1,200 \\
1,100 \\
2,300 \\
900 \\
\text { Lost } \\
1,100 \\
490 \\
690 \\
-\end{array}$ \\
\hline
\end{tabular}

TABLE 3. Analysis of possible potable water in the Detah area

\begin{tabular}{|c|c|c|c|c|c|c|c|}
\hline \multirow[b]{2}{*}{ Date } & \multirow[b]{2}{*}{ Station } & \multirow{2}{*}{$\begin{array}{c}\text { Total } \\
\text { coliform } \\
\text { per } 100 \mathrm{ml}\end{array}$} & \multirow{2}{*}{$\begin{array}{c}\text { Faecal } \\
\text { coliform } \\
\text { per } 100 \mathrm{ml}\end{array}$} & \multirow{2}{*}{$\begin{array}{c}\text { Faecal } \\
\text { streptococci } \\
\text { per } 100 \mathrm{ml}\end{array}$} & \multicolumn{2}{|c|}{$\begin{array}{l}\text { Standard plate } \\
\text { counts per ml }\end{array}$} & \multirow{2}{*}{$\begin{array}{c}\begin{array}{c}\text { Spread plate } \\
\text { counts per ml }\end{array} \\
20^{\circ} \mathrm{C}\end{array}$} \\
\hline & & & & & $35^{\circ} \mathrm{C}$ & $20^{\circ} \mathrm{C}$ & \\
\hline 3 Oct. & $\begin{array}{l}\text { AA } \\
\text { BB } \\
\text { CC } \\
\text { DD } \\
\text { EE } \\
\text { FF } \\
\text { GG }\end{array}$ & $\begin{array}{r}16 \\
2 \\
78 \\
20 \\
14 \\
12 \\
1\end{array}$ & $\begin{array}{r}2 \\
1 \\
3 \\
2 \\
1 \\
1 \\
<1\end{array}$ & $\begin{array}{r}1 \\
1 \\
3 \\
<1 \\
<1 \\
<1 \\
<1\end{array}$ & $\begin{array}{r}0 \\
22 \\
14 \\
33 \\
10 \\
4 \\
27\end{array}$ & $\begin{array}{l}43 \\
60 \\
76 \\
73 \\
41 \\
35 \\
28\end{array}$ & $\begin{array}{r}530 \\
560 \\
- \\
-\overline{660} \\
990 \\
470\end{array}$ \\
\hline
\end{tabular}

it must be recognized that the coliform standard provides no guarantee of absolute safety. In 1962, 45,000 cases of gastroenteritis and 38 cases of typhoid were reported in Detroit, Michigan, where the coliform values were reported to be 6.5 per $100 \mathrm{ml}$ (Berger et al. 1963). Similarly, a large outbreak of Salmonella typhimurium was reported in Riverside, California, where no coliforms were observed in the drinking water (Geldreich 1972). It is evident that any person consuming raw water from the areas studied jeopardizes his own health unless he first disinfects that water.

The sewage effluent discharged into Back Bay is of poor bacterial quality, with a geometric mean faecal coliform value of 5,400 per $100 \mathrm{ml}$ (Table 4). The effluent (average $3.1 \times 10^{6}$ litres per day) produces only a localized effect on Back Bay (see Fig. 2). The direction of flow appears to be a function of weather and of channelling caused by sand bars in the area of discharge. During periods of easterly winds and high wave action in the bay, the flow appears to 


\section{TABLE 4. Analysis of Yellowknife sewage}

\begin{tabular}{|c|c|c|c|c|c|c|c|}
\hline \multirow[b]{2}{*}{ Date } & \multirow{2}{*}{$\begin{array}{c}\text { Total } \\
\text { coliform } \\
\text { per } 100 \mathrm{ml}\end{array}$} & \multirow{2}{*}{$\begin{array}{l}\text { Faecal } \\
\text { coliform } \\
\text { per } 100 \mathrm{ml}\end{array}$} & \multirow{2}{*}{$\begin{array}{c}\text { Faecal } \\
\text { streptococci } \\
\text { per } 100 \mathrm{ml}\end{array}$} & \multirow{2}{*}{ F.C./F.S. } & \multicolumn{2}{|c|}{$\begin{array}{l}\text { Standard plate } \\
\text { counts per ml }\end{array}$} & \multirow{2}{*}{$\begin{array}{c}\begin{array}{c}\text { Spread } \\
\text { plate } \\
\text { counts } \\
\text { per ml }\end{array} \\
20^{\circ} \mathrm{C}\end{array}$} \\
\hline & & & & & $30^{\circ} \mathrm{C}$ & $20^{\circ} \mathrm{C}$ & \\
\hline $\begin{array}{l}\text { Raw sewage in } \\
3 \text { Sept. } \\
29 \text { Sept. } \\
30 \text { Sept. } \\
1 \text { Oct. } \\
2 \text { Oct. } \\
3 \text { Oct. } \\
7 \text { Oct. } \\
8 \text { Oct. } \\
\text { Arith. mean } \\
\text { Geom. mean } \\
\text { Median }\end{array}$ & $\begin{array}{r}\text { luent } \\
5,600,000 \\
46,000,000 \\
23,000,000 \\
39,000,000 \\
19,000,000 \\
96,000,000 \\
21,000,000 \\
74,000,000 \\
40,000,000 \\
30,000,000 \\
31,000,000\end{array}$ & $\begin{array}{r}840,000 \\
5,200,000 \\
2,400,000 \\
1,900,000 \\
8,300,000 \\
17,000,000 \\
800,000 \\
840,000 \\
4,700,000 \\
2,600,000 \\
2,200,000\end{array}$ & $\begin{array}{c}200,000 \\
400,000 \\
550,000 \\
570,000 \\
410,000 \\
5,600^{*} \\
580,000 \\
150,000 \\
360,000 \\
220,000 \\
410,000\end{array}$ & $\begin{array}{r}4.20 \\
13.00 \\
4.37 \\
3.33 \\
20.24 \\
1.38 \\
5.60 \\
7.45 \\
5.34 \\
4.37\end{array}$ & $\begin{array}{r}200,000 \\
190,000 \\
1,000,000 \\
780,000 \\
690,000 \\
380,000 \\
770,000 \\
770,000 \\
600,000 \\
510,000 \\
770,000\end{array}$ & $\begin{array}{r}1,900,000 \\
160,000 \\
1,200,000 \\
1,700,000 \\
1,300,000 \\
1,500,000 \\
1,100,000 \\
970,000 \\
1,200,000 \\
1,000,000 \\
1,300,000\end{array}$ & $\begin{array}{r}5,700,000 \\
\text { Lost } \\
3,800,000 \\
\text { Lost } \\
860,000 \\
4,400,000 \\
30,000,000 \\
14,000,000 \\
9,700,000 \\
5,600,000 \\
4,800,000\end{array}$ \\
\hline $\begin{array}{l}\text { effluent in Bac } \\
3 \text { Sept. } \\
29 \text { Sept. } \\
30 \text { Sept. } \\
1 \text { Oct. } \\
2 \text { Oct. } \\
3 \text { Oct. } \\
4 \text { Oct. } \\
7 \text { Oct. } \\
8 \text { Oct. } \\
\text { Arith. mean } \\
\text { Geom. mean } \\
\text { Median }\end{array}$ & $\begin{array}{r}110,000 \\
340,000 \\
290,000 \\
210,000 \\
170,000 \\
83,000 \\
87,000 \\
170,000 \\
120,000 \\
180,000 \\
160,000 \\
170,000\end{array}$ & $\begin{array}{r}13,000 \\
9,100 \\
4,900 \\
7,300 \\
25,000 \\
4,500 \\
1,100 \\
3,300 \\
5,600 \\
7,600 \\
5,400 \\
5,300\end{array}$ & $\begin{array}{r}1,300 \\
2,200 \\
1,900 \\
1,600 \\
2,500 \\
750 \\
970 \\
1,300 \\
2,800 \\
1,800 \\
1,600 \\
1,800\end{array}$ & $\begin{array}{r}10.00 \\
4.14 \\
2.58 \\
4.56 \\
10.00 \\
6.00 \\
1.13 \\
2.54 \\
2.00 \\
4.12 \\
3.37 \\
3.36\end{array}$ & $\begin{array}{r}7,500 \\
6,400 \\
44,000 \\
9,600 \\
6,700 \\
11,000 \\
3,300 \\
9,200 \\
7,200 \\
12,000 \\
9,000 \\
8,200\end{array}$ & $\begin{array}{l}16,000 \\
12,000 \\
22,000 \\
57,000 \\
64,000 \\
74,000 \\
21,000 \\
23,000 \\
13,000 \\
36,000 \\
29,000 \\
23,000\end{array}$ & $\begin{array}{r}1,000,000 \\
600,000 \\
1,100,000 \\
\text { Lost } \\
920,000 \\
900,000 \\
660,000 \\
1,900,000 \\
2,200,000 \\
1,200,000 \\
1,100,000 \\
920,000\end{array}$ \\
\hline
\end{tabular}

* Data considered erroneous.

be to the south and likely accounts for the high coliform value of 47,000 per $100 \mathrm{ml}$ at potable water station E. During calm weather the flow is to the north. The effects are only detectable within 6-15 metres of the shore and approximately 100-200 metres either side of the point of discharge. Sterilization of the effluent may lead to an overall lowering of the bacterial values in the study area, although absolute predictions cannot be made.

The bacterial values were noted to be higher in Sector 1 (see Table 1), and these elevated numbers may be due in part to the influences of the sewage effluent. Other point sources of pollution which may account for the higher numbers are storm drains flowing into the bay in the southern section, bottom muds, marsh mud and marsh waters in the southernmost part of the bay. Geldreich and Kenner (1969) have developed the concept of faecal coliform to faecal streptococci F.C./F.S. ratio as a means of determining the source of contamination. In a large sampling of non-human animal wastes they found this ratio to be consistently less that $\mathbf{0 . 7}$, and for human sources consistently greater than 4.0. The age of the sample and time it has been away from source are important factors in assessing these ratios, due to the differential die-away rates of faecal coliforms and faecal streptococci. Feachem (1975) has demonstrated an improved role for the use of the F.C./F.S. ratio; he concludes that if it is initially high and then falls, human contamination is indicated whereas if it is initially low and subsequently rises, a 
non-human source is indicated. Even though elevated values were observed at the other point sources (Table 5), analyses of F.C./F.S. ratios indicate that the sources of bacteria were either of animal origin or non-human. The large dog population may account for this circumstance, and the ratios lead the present authors to believe that the storm sewers sampled do not possess a high domestic waste content.

TABLE 5. Analysis of samples taken during heavy rainfall at storm drains and near mud and marshes

\begin{tabular}{|c|c|c|c|c|c|c|c|}
\hline & \multirow{2}{*}{$\begin{array}{c}\text { Total } \\
\text { coliform } \\
\text { per } 100 \mathrm{ml}\end{array}$} & \multirow{2}{*}{$\begin{array}{c}\text { Faecal } \\
\text { coliform } \\
\text { per } 100 \mathrm{ml}\end{array}$} & \multirow{2}{*}{$\begin{array}{l}\text { Faecal } \\
\text { streptococci } \\
\text { per } 100 \mathrm{ml}\end{array}$} & \multirow{2}{*}{ F.C./F.S. } & \multicolumn{2}{|c|}{$\begin{array}{l}\text { Standard plate } \\
\text { counts per ml }\end{array}$} & \multirow{2}{*}{$\begin{array}{c}\begin{array}{c}\text { Spread } \\
\text { plate } \\
\text { counts } \\
\text { per ml }\end{array} \\
20^{\circ} \mathrm{C}\end{array}$} \\
\hline & & & & & $35^{\circ} \mathrm{C}$ & $20^{\circ} \mathrm{C}$ & \\
\hline 1. Storm drain & 87,000 & 17,000 & 24,000 & 0.71 & 9,300 & 67,000 & $1,200,000$ \\
\hline 2. Storm drain & 7,100 & 1,600 & 19,000 & 0.08 & 4,500 & 75,000 & 560,000 \\
\hline 3. Storm drain & 1,400 & 200 & 2,600 & 0.08 & 1,300 & 22,000 & 590,000 \\
\hline 4. Storm drain & 1,300 & 300 & 1,800 & 0.17 & 920 & 9,800 & 480,000 \\
\hline 5. Marsh mud & 19,000 & 300 & 10 & - & 7,500 & 58,000 & $12,000,000$ \\
\hline $\begin{array}{l}\text { 6. Mud from } \\
\text { water quality } \\
\text { monitoring } \\
\text { station no. } 1\end{array}$ & 18,000 & 10 & 10 & - & 460 & 4.300 & 170,000 \\
\hline 7. Marsh water & 700 & 20 & 100 & 0.20 & 920 & 6,500 & $1,300,000$ \\
\hline 8. Marsh water & 620 & 90 & 80 & 1.13 & 220 & 6,000 & 260,000 \\
\hline 9. Marsh water & 6,200 & 160 & 80 & 2.00 & 620 & 12,000 & 660,000 \\
\hline
\end{tabular}

\section{CONCLUSIONS}

Because of the local attitudes towards water usage in the North, where sources of it are generally considered to be of good quality and safe to drink from, the authors recognize that the most difficult task is that of educating the local inhabitants to the dangers of water consumption without proper sterilization. It is clear that, in general, the bacterial state of the waters of Back Bay and Yellowknife Bay is good, but nevertheless, not such that they can be drunk without prior treatment.

The City of Yellowknife should seek an alternative disposal site and, in the interim, have the waste discharge from Niven Lake disinfected. Such action will not remove all the bacterial pathogens or viruses that may be found in the study area, but should provide a great reduction in their numbers from the major source, the city's sewage.

If urban communities are to develop in the North, it is obvious that sewage disposal and water supply must be given high priority. Disposal of improperly treated wastes such as that found in Yellowknife should not be allowed; and, in the event that waters become contaminated, the users must be warned through adequate publicity, and the responsible authorities ensure that domestic use is either stopped, or precautionary measures taken. 


\section{REFERENCES}

A.P.H.A. 1971. Standard Methods for the Examination of Water and Wastewater. Washington, D.C.: American Public Health Association.

BELL, J. B. 1975. The Bacteriological Content of the North Saskatchewan River in the Vicinity of Edmonton, Alberta. Ottawa: Environment Canada (Manuscript Report E.P.S.-5-NW-75-2)

and JURkovic, A. A. 1975. Morphology, nutritional requirements and physiological activity of heterotrophic bacteria isolated from a deep water sediment core in Lake Ontario. Acta Hydrobiologica, 17 (2): 95-102.

and VANDERPOST, J. M. 1973. Comparison of membrane filtration methods in the isolation of coliforms. Proceedings, 16th Conference on Great Lakes Research, 1973. Ann Arbor, Michigan: Braun-Brumfield. pp. 15-20.

BERGER, B. C., JENSEN, E. D., LUDWID, H., ROVER, H., SHAPIRO, M. A. and SEN, C. 1963. Coliform standards for recreational waters. Journal of the Sanitary Engineering Division, American Society of Civil Engineers, 89 (4): 51.

D.N.H.W. 1968. Canadian Drinking Water Standards and Objectives 1968. Ottawa: Department of National Health and Welfare.

DUTKA, B. J. and BELL, J. B. 1973. Isolation of Salmonella from moderately polluted waters. Journal of the Water Pollution Control Federation, 45 (2): 316-24.

FEACHEM, R. 1975. An improved role for faecal coliform to faecal streptococci ratios in the differentiation between human and non-human pollutions sources. Water Research, 9: 689-90.

GELDREICH, E. E. 1972. Waterborne pathogens. In: Mitchel, R. (ed.), Water Pollution Microbiology, New York: Wiley, pp. 207-41.

GELDREICH, E. E. and KENNER, B. A. 1969. Concepts of faecal streptococci in stream pollution. Journal of the Water Pollution Control Federation, 41 (8): R226-R352.

GORDON, R. C. 1972. Winter Survival of Faecal Indicator Bacteria in a Subarctic Alaskan River. Corvallis, Oregon: U.S. Environmental Protection Agency (Report E.P.A.-R2-72-013).

GRAINGE, J. 1971. Study of the Sewage Oxidation Ponds, City of Yellowknife, Northwest Territories. Edmonton, Alberta: Department of Environment, Public Health Engineering Division (Government of Canada).

HEINKE, G. W. and DEANS, B. 1973. Water supply and waste disposal systems for Arctic communication. Arctic, 26 (2): 149-59.

MC CABE, L. J. and CRAUN, G. F. 1974. Status of waterborne diseases in the U.S. and Canada. Journal of the American Water Works Association, 567 (2): 95-98.

PICK, A. 1975. Review of Proposed Sewage Disposal to Kam Lake, Northwest Territories. Ottawa: Environment Canada (Manuscript Report E.P.S.-8-NW-74-1).

VAN DONSEL, D. J., GORDON, R. C. and DAVENPORT, c. v. 1974. Preliminary Study Comparative Winter Survival of Faecal Bacteria in a Subarctic River. College, Alaska: U.S. Environmental Protection Agency (Arctic Environmental Research Laboratory, Working Paper no. 28).

YAMомото, T. 1975. Preliminary Analysis of Enteric Virus Content of Wastewaters in Selected Communities in the Northwest Territories and Alberta. Edmonton, Alberta: University of Alberta (Research Report). 